Çukurova Üniversitesi Mühendislik Mimarlık Fakültesi Dergisi, 35(3), ss. 821-834, Eylül 2020

Cukurova University Journal of the Faculty of Engineering and Architecture, 35(3), pp. 821-834, September 2020

\title{
24 Ocak 2020 Elazı̆̆ Depreminin Kuvvetli Yer Hareketi Verilerinin Değerlendirilmesi
}

\author{
Abdullah Can ZÜLFIKAR*1

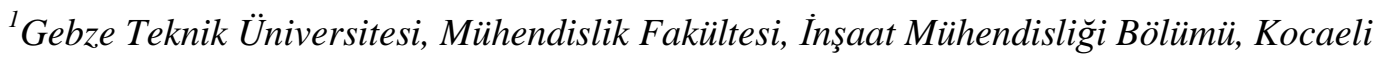

Geliş tarihi: 21.09 .2020

Kabul tarihi: 23.10 .2020

\section{Özet}

24 Ocak 2020 tarihinde yerel saatle 20.55’te Elazığ-Sivrice (Türkiye) ilinde, merkez üssü Sivrice ilçesi, Çevrimtaş köyü olan ve yaklaşı 40 saniye kadar süren $\mathrm{M}_{\mathrm{w}} 6,8$ büyüklüğünde deprem meydana gelmiştir. Deprem başta Elazığ ve Malatya olmak üzere, Adıyaman, Kahramanmaraş, Adana, Hatay, Osmaniye, Tunceli, Gaziantep, Şanlıurfa gibi birçok ilde hissedilerek paniğe yol açmıştır.

Bu çalışma kapsamında Mw 6,8 Sivrice depremine ait yer hareketi kayıtları incelenmiştir. Yer hareketi parametresi Maksimum Yer İvmesi (PGA), 2014 Yeni Nesil Azalım İlişkileri (Next Generation Attenuation Relations)-Yer Hareketi Tahmin Denklemleri (YHTD) kullanılarak değerlendirilmiştir. Ayrıca yer hareketi parametreleri (MMI, PGA, Sa 0,2, Sa 1,0) dağılım haritaları oluşturularak, kaydedilmiş yer hareketi kayıtları ile karşılaştırılmıştır. Bunların yanısıra, öncü/artçı depremler incelenerek Doğu Anadolu Fay Zonu depremlerinin karakteristiği ortaya konmuştur. Ortaya çıkan enerji miktarı geçmiş büyük ölçekli depremler ile karşılaştırılmıştır.

Anahtar Kelimeler: 24 Ocak 2020 Mw6.8 Elazığ-Sivrice depremi, Yer hareketi parametreleri

\section{Evaluation of Strong Ground Motion Records of January 24, 2020 Elazı $\breve{g}$ Earthquake}

\begin{abstract}

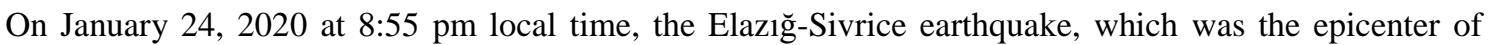
Sivrice with a north latitude of 39.10 east longitudes of 38.35 and a magnitude (Mw) of 6.8 occurred. The earthquake was felt especially in the nearby cities Elazig and Malatya. Many other cities such as Adıyaman, Kahramanmaraş, Adana, Hatay, Osmaniye, Tunceli, Gaziantep, Şanlıurfa cities in the region were affected from the earthquake as well.

In this study, the ground motion records of the Elazığ-Sivrice earthquake were examined. Ground motion parameters; Spectral acceleration (SA) and Peak Ground Acceleration (PGA) have been evaluated by 2014 Next Generation Attenuation relations. In addition, the ground motion parameters (MMI, PGA, $\mathrm{Sa} 0.2$, Sa1.0) distribution maps were created and compared with the recorded ground motions. In addition to these, the characteristics of the East Anatolian fault zone earthquakes were revealed, by examining the
\end{abstract}

*Sorumlu yazar (Corresponding Author): Abdullah Can ZÜLFİKAR, aczulfikar@gtu.edu.tr 
foreshocks/aftershocks. The amount of energy released has been compared with past large-scale earthquakes.

Keywords: January 24, $2020 \mathrm{M}_{\mathrm{w}} 6.8$ Elazig-Sivrice earthquake, Ground motion parameters

\section{GíRiș}

Türkiye dünyanın en aktif deprem kuşaklarından biri olan Alp-Himalaya deprem kuşağ yer almaktadır. Ülke yüzölçümünün \%43'ü birinci derece deprem kuşağı olarak tanımlanan beklenen ivme değeri 0,40 g'dan büyük alanlarda yer almaktadır. Geçmişten günümüze Türkiye'de gelişen depremler can ve mal kaybına yol açarak büyük hasarlara yol açmıştır.

Mw 6,8 Elazı ̆ depremi 24 Ocak 2020 tarihinde Türkiye yerel saati $20: 55$ ' de $8 \mathrm{~km}$ derinlikte meydana gelmiştir [1]. Deprem başta Elazı ğ ve Malatya olmak üzere, Adıyaman, Kahramanmaraş, Adana, Hatay, Osmaniye, Tunceli, Gaziantep, Şanlıurfa gibi birçok ilde hissedildi. Deprem sonrasında Elazı̆̆g, Malatya, Kahramanmaraş, Diyarbakır, Şanlıurfa, Adıyaman ve Batman'da birçok binanın hasar aldığı yapılan incelemeler ile belirlenmiştir. Aynı zamanda, 37'si Elazı̆̆, 4'ü Malatya'da olmak üzere 41 kişinin hayatını kaybetmiş, 1466 kişi ise hafif ve orta derecede yaralanmıştır [1]. Deprem sonrası yapılan odak mekanizma çözümleri ve çalışmalar ile depremin sol yanal doğrultu atım karakterli Doğu Anadolu Fay Zonu Pütürge segmenti üzerinde olduğu tespit edilmiştir [2]. 24 Ocak 2020 Elazı̆̆ depremi sonrasında, büyüklükleri 0,8 ile 5,4 arasında değişen 4322 artçı sarsıntı meydana gelmiştir. Artçı şokların 30'u 4 ve üzeri büyüklükte gerçekleşmiştir. Artçı şokların merkez üsleri Elazığ'ın Sivrice ve Baskil ilçeleri ile Malatya'nın Kale, Pütürge, Doğanyol ve Battalgazi ilçeleri olarak tespit edilmiştir. 20 Ocak Elazığ depremi, 2010'da Doğu Anadolu Fay Zonunda meydana gelen Kovancılar depreminden sonra bölgeyi etkileyen en büyük deprem olması nedeni ile önemlidir.

$\mathrm{Bu}$ çalışmada, Elazı̆̆ depreminin etki ettiği bölgelerin (Şekil 1) Sismo-tektonik aktivitesi, depreme ait kuvvetli yer hareketi verileri ile detaylı olarak incelenmiştir. Çalışma kapsamında, depremin merkezine yakın istasyonlardan alınan yer hareketi kayıtları değerlendirilmiş, yer hareketi parametrelerinin uzaklık ile değişimi ve 2014 Yeni Nesil Azalım İlişkileri [3] (NGA-Next Generation Attenuation)-Yer Hareketi Tahmin Denklemleri (YHTD) ile uyumu incelenmiştir. Depremin etki alanındaki yer hareketi parametreleri; (MMIModified Mercalli Intensity-Şiddet, PGAMaksimum Yer İvmesi, $S_{a} 0,2$ sn $S_{a} 1,0$ sn Spektral İvme) dağılım haritaları elde edilmiştir. Ayrıca öncü ve artçı depremler değerlendirilerek orta ölçekli bölgesel depremlerinin karakteristiği ortaya konmuştur.

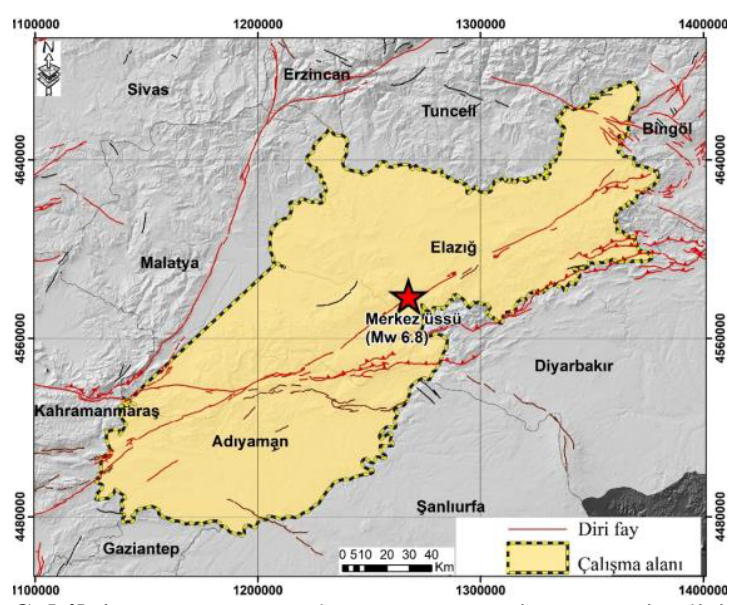

Şekil 1. Deprem merkez üssü ve civarına ait diri fay haritas1 [4]

\section{MATERYAL VE YÖNTEM}

\subsection{Sismotektonik Değerlendirme}

Arabistan plakası ile Anadolu bloğu arasındaki sınırı oluşturan sol-yanal doğrultu atımlı Doğu Anadolu Fayı (DAF), kuzeydoğuda Karlıova'da Kuzey Anadolu Fay hattı (KAF) ve güneybatıda Kahramanmaraş dolayında Ölü Deniz Fayı (ÖDF) ile kesişmektedir. Genel doğrultusu KD-GB olan DAF yaklaşık $580 \mathrm{~km}$ uzunluğundadır [4]. Sol 
yönlü doğrultu atım özelliği gösteren DAF, Karlıova, Ilıca, Palu, Pütürge, Erkenek, Pazarcık ve Amanos olmak üzere 6 segmentten oluşmaktadır (Çizelge 1). Türkiye'nin tektonik yapısı açısından önemli bir yere sahip olan DAF, Anadolu Plakasının batıya hareketi nedeniyle üzerinde 4-13 mm/yıl civarı sol-yanal karakterde bir deformasyona ya da varsa sürtünmenin düşük olduğu yerlerde durağan kaymaya ev sahipliği etmektedir [5-11]. Doğu Anadolu fay zonu, tarihsel ve aletsel dönemde, 6 ve üzeri büyüklüğünde yıkıcı birçok depreme sebep olmuştur. DAF'1 oluşturan segmentlerin uzunluklarına göre segmentler üzerinde aletsel büyüklüğü 6 ve daha büyük deprem üretme potansiyeline sahip olduğu bilinmektedir.

Çizelge 1. Doğu Anadolu Fay Zonu ve içerisinde yer alan segmentlere ait yapisal bilgiler[4]

\begin{tabular}{|c|c|c|c|c|c|c|}
\hline & & 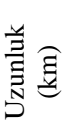 & : & $\begin{array}{c}\text { Kayma } \\
\text { türü }\end{array}$ & $\begin{array}{l}\text { Genel } \\
\text { trend }\end{array}$ & $\begin{array}{c}\text { Fay } \\
\text { düzleminin } \\
\text { eğim yönü } \\
\text { ve derecesi }\end{array}$ \\
\hline Fay & DAFZ & 580 & Holosen & SYDA & & \\
\hline \multirow{7}{*}{ 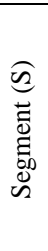 } & Karlıova S. & 31 & Holosen & SYDA & K50D & Düşey \\
\hline & Ilıca S. & 40 & DYK & SYDA & K40D & Düşey \\
\hline & Palu S. & 77 & Holosen & SYDA & K62D & Düşey \\
\hline & Pütürge $S$. & 96 & Holosen & SYDA & K60D & Düşey \\
\hline & Erkenek S. & 62 & Holosen & SYDA & K75D & Düşey \\
\hline & Pazarcık S. & 82 & Holosen & SYDA & K60D & Düşey \\
\hline & Amanos S. & 112 & Holosen & SYDA & K35D & Düşey \\
\hline
\end{tabular}

SYDA: Sol yönlü doğrultu atımlı; DAFZ: Doğu Anadolu Fay Zonu; DYK: Deprem Yüzey Kırığı

Aletsel deprem kataloğuna [12], [1] $\mathrm{M}_{\mathrm{s}}=6,8$ büyüklüğünde 4 Aralık 1905 tarihinde gelişen depremden sonra bölgede gelişen en büyük deprem 24 Ocak $2020 \mathrm{M}_{\mathrm{w}}$ 6,8 Elazı ğ depremidir. Çalışma alanına ait aletsel deprem kayıtlarına göre 4 ve üzeri büyüklükte 225 adet deprem kaydı bulunmaktadır (Şekil 2a). Bu depremlerin 6'sı 6 ve üzeri, 34 tanesi 5-6 büyüklüğü arasındadır. Tarihsel deprem kayıtlarına göre çalışma alanında (Şekil 2b) 34 deprem kaydı bulunmaktadır [13]. Bu depremlerden MS 240 tarihinde Kayseri, Sivas, Malatya'da hissedildiği kayıtlarda yer alan IX şiddetindeki deprem ile MS 1046'da gelişen Diyarbakır, Elazığ ve Karakoçan’da meydana gelen X şiddetindeki deprem büyük hasara yol açmıştır.

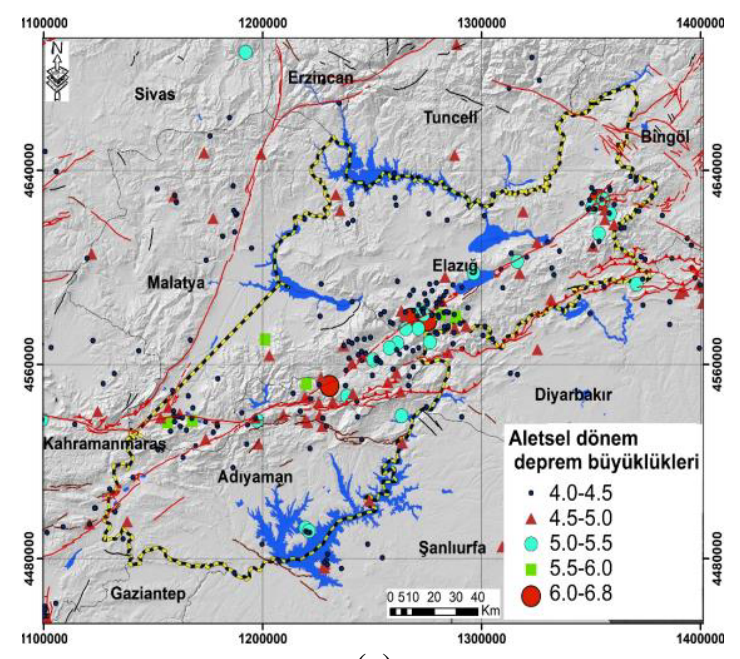

(a)

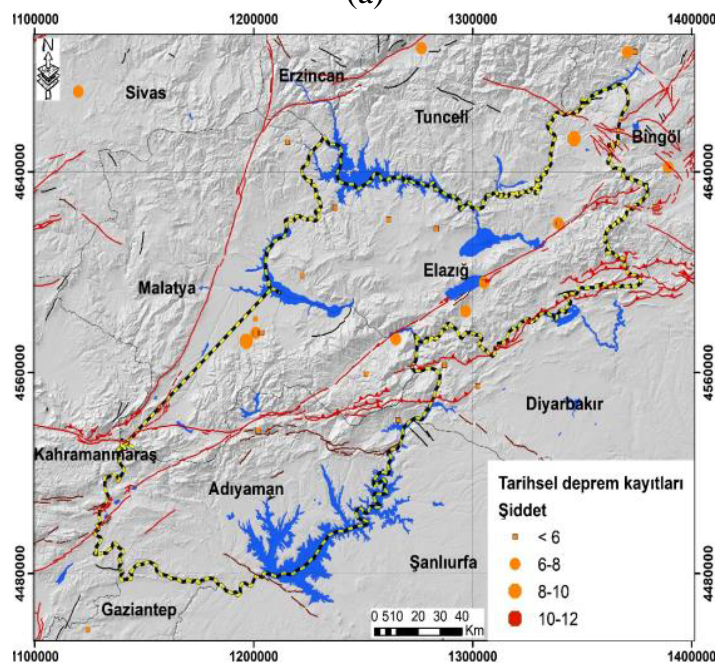

(b)

Şekil 2. Aletsel [12], [1] (a) ve Tarihsel (b) [13] deprem kayitları

\section{BULGULAR VE TARTIŞMA}

\subsection{Kuvvetli Yer Hareketi Kayıtları}

Mw 6,8 büyüklüğündeki Elazığ/Sivrice depremi Elazığ ve çevre şehirlerde büyük yapısal hasarlara ve can kayıplarına sebep olmuştur. Deprem yer hareketi kayıtları AFAD tarafından bölgede kurulu 
olan yer hareketi kayıt istasyonlarında kaydedilmiştir. Çizelge 2'de bölgede mevcut yer hareketi kayıt istasyonları ve yer hareketi kayıtları hakkında bilgi verilmiştir, ayrıca, Şekil 3'de istasyon konumları ve her bir istasyonda kaydedilen PGA değerleri harita üzerinde gösterilmiştir. İstasyon kayıtları [14]'den alınmıştır. AFAD'dan alınan verilere göre sadece bazı istasyonların $\mathrm{V}_{\mathrm{s}, 30}$ değeri bulunmamaktadır. $\mathrm{Bu}$ istasyonlar için $\mathrm{V}_{\mathrm{s}, 30}$ değeri bölge için mevcut yüzey jeoloji bilgisi kullanılarak $360 \mathrm{~m} \mathrm{~s}^{-1}$ (zemin sınıfı ZC) kabulü yapılmıştır. Elazı̆̆/Sivrice depremi esnasında AFAD istasyonlarından Sivrice (2308) istasyonunda maksimum yer ivmesi $2,92 \mathrm{~m} \mathrm{~s}^{-2}$ olarak okunmuştur.

Çizelge 2. Mw 6,8 Elazı $\breve{g} /$ Sivrice açıkları depremi yer hareketi kayıt istasyon bilgileri [14]

\begin{tabular}{|c|c|c|c|c|}
\hline İstasyon İD & İl/İlçe & $\mathrm{Vs} 30(\mathrm{~m} / \mathrm{s})$ & PGA(gal) & Repi (km) \\
\hline 2308 & Elazığg-Sivrice & 450 & $292,80(\mathrm{EW})$ & 23,81 \\
\hline 4404 & Malatya-Pütürge & 1380 & $228,44(\mathrm{EW})$ & 24,55 \\
\hline 2301 & Elazı ̆̆-Merkez & 407 & $137,78(\mathrm{EW})$ & 36,39 \\
\hline 0204 & Adıyaman-Gerger & 555 & $110,12(\mathrm{EW})$ & 36,81 \\
\hline 0212* & Adiyaman-Sincik & 360 & $43,52(\mathrm{NS})$ & 53,21 \\
\hline 2302 & Elazı̆̆g-Maden & 907 & $31,36(\mathrm{EW})$ & 53,51 \\
\hline 2104 & Diyarbakır-Ergani & 360 & $26,75(\mathrm{NS})$ & 61,64 \\
\hline 4401 & Malatya-Battalgazi & 481 & $87,63(\mathrm{EW})$ & 63,04 \\
\hline 0205 & Adiyaman-Kahta & 660 & $41,01(\mathrm{EW})$ & 74,25 \\
\hline 0207 & Adıyaman-Çelikhan & 660 & $31,56(\mathrm{NS})$ & 80,00 \\
\hline 2304 & Elazı $\breve{g}-$ Kovancılar & 489 & $13,74(\mathrm{EW})$ & 80,36 \\
\hline $4412 *$ & Malatya- Yazıhan & 360 & $21,46(\mathrm{NS})$ & 80,96 \\
\hline 4407 & Malatya- Arguvan & 435 & $31,05(\mathrm{NS})$ & 83,78 \\
\hline 2307 & Elazığ-Palu & 329 & $20,83(\mathrm{EW})$ & 84,35 \\
\hline $2105^{*}$ & Diyarbakır-Dicle & 360 & $11,09(\mathrm{EW})$ & 87,92 \\
\hline $6201 *$ & Tunceli-Merkez & 360 & $11,99(\mathrm{NS})$ & 89,46 \\
\hline 0210* & Adiyaman-Merkez & 360 & $27,43(\mathrm{EW})$ & 94,63 \\
\hline 4406 & Malatya- Akçadağ & 815 & $24,02(\mathrm{EW})$ & 95,00 \\
\hline 0201 & Adiyaman-Merkez & 391 & $44,61(\mathrm{EW})$ & 96,30 \\
\hline $0209 *$ & Adiyaman-Samsat & 360 & $70,85(\mathrm{NS})$ & 100,72 \\
\hline
\end{tabular}

$* \mathrm{~V}_{\mathrm{s}, 30}$ değeri bulunmayan istasyonlar

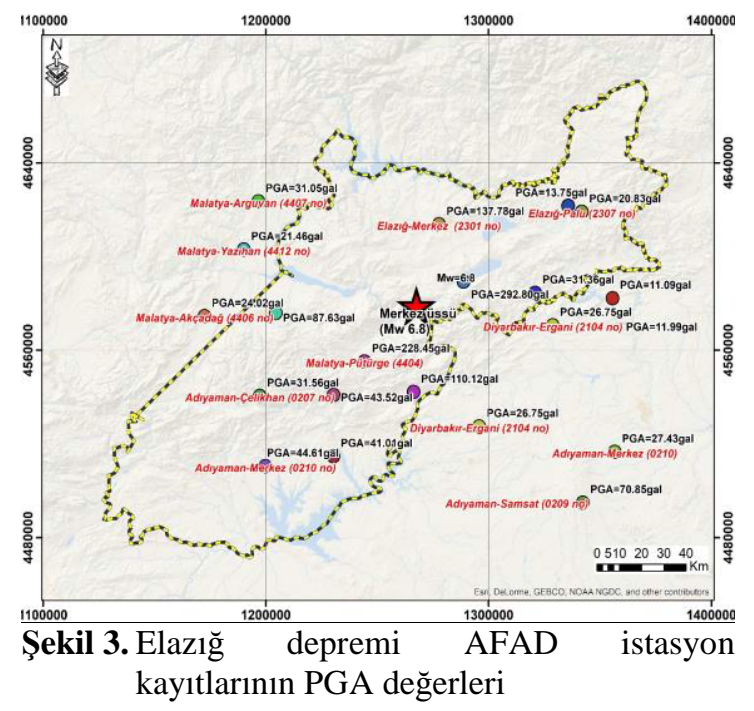

AFAD veri tabanından alınan istasyon kayıt bilgilerine göre deprem merkezine en fazla $50 \mathrm{~km}$ uzaklıkta bulunan istasyon verileri incelenmiştir. 2308, 4404, 2301, 0204, 0212, 2302, 2104 numaralı istasyonlar depremin merkezine $50 \mathrm{~km}$ uzaklıkta bulunan AFAD istasyonlarıdır. Sivrice depremine ait 2308, 4404, 2301, 0204, 0212, 2302, 2104 numaralı istasyonlara ait filtrelenmiş deprem ivme kayıtları zaman tanım alanında Şekil 4'de ve frekans tanım alanında Şekil 5'de görülmektedir. Şekil 4 ve Çizelge 2'de görüldüğü üzere ivme değerleri 2308-Sivrice, 4404-Pütürge ve 2301Elazığ-Merkez istasyonlarında daha yüksek değerler göstermektedir. 


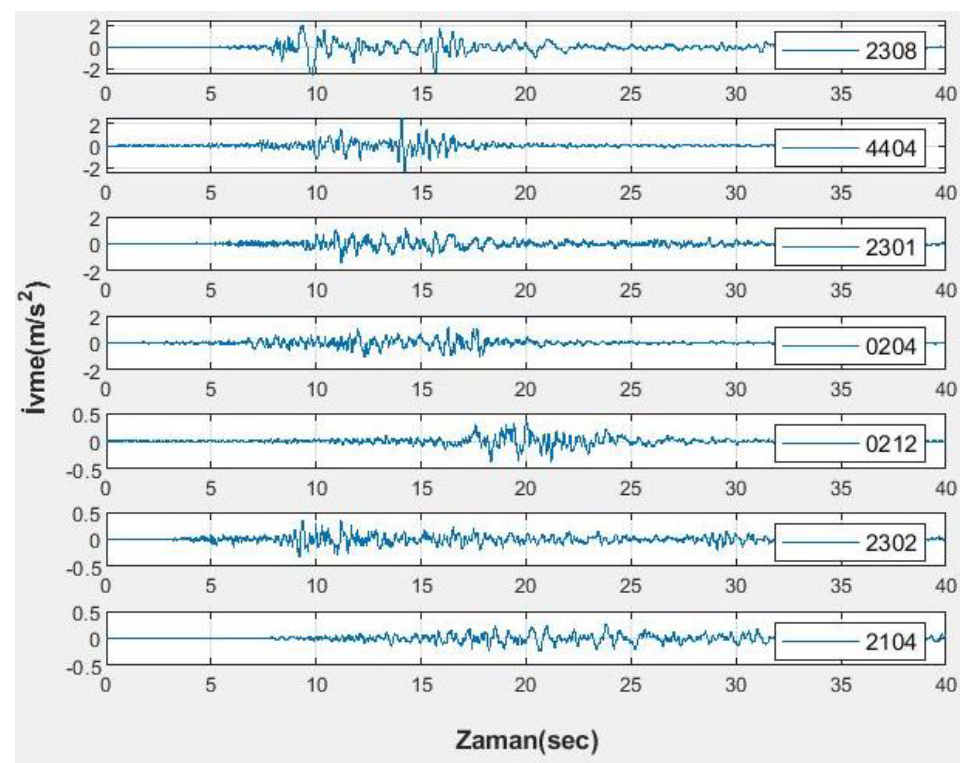

Şekil 4. Filtrelenmiş yedi farklı istasyona ait ivme kayıtları

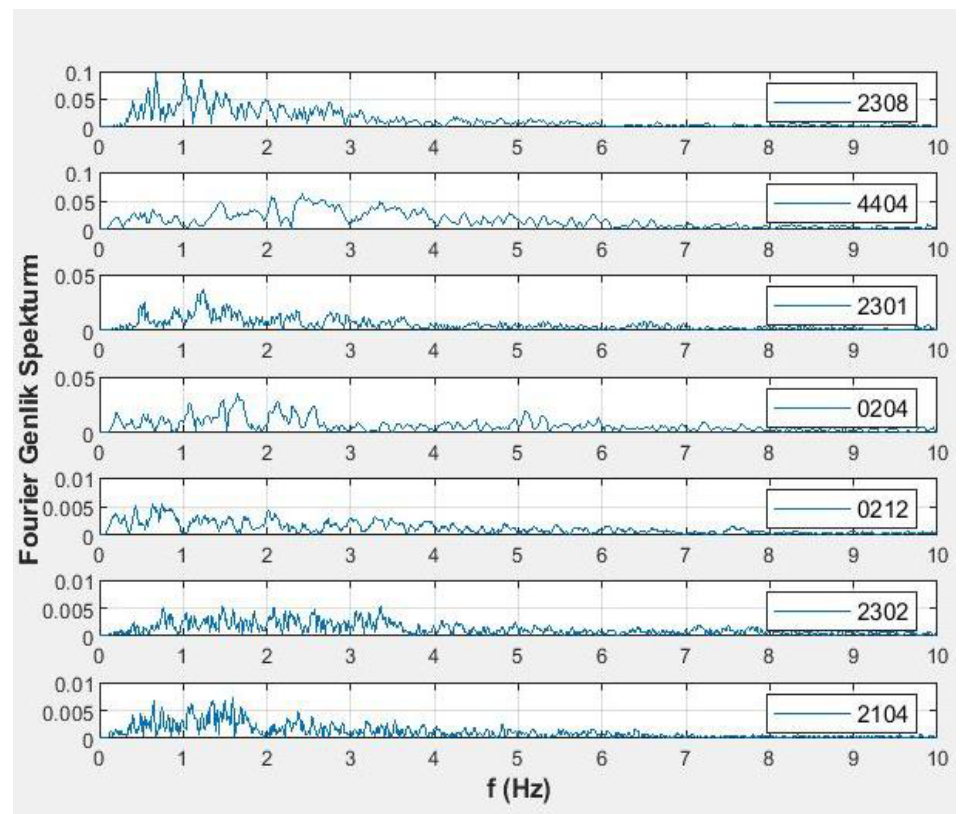

Şekil 5. Seçilen kayıtların fourier genlik spektrumu

Çalışma kapsamında 2014 yer hareketi tahmin denklemleri (2014-YHTD) [3] kullanılarak kaydedilen yer hareketi parametreleri ile karşılaştırmalar yapılmıştır. Bu YHTD bölgesel yüzey jeoloji haritalarından elde edilen bölgedeki zemin yapısı ile ilişkilendirilmiş üst 30 m'deki ortalama kayma dalgası hızı $\left(\mathrm{V}_{\mathrm{s}, 30}\right)$, faya olan uzaklık, fay tipi, derinlik, fay mekanizması, deprem ve istasyon bilgileri parametrelerini kullanmaktadır. 
PEER (Pasifik Deprem Mühendisliği Araştırma Merkezi) tarafından geliştirilen NGA modelleri olarak bilinen YHDT'leri, 2014 yılında Türkiye de dahil olmak üzere bölgesel faktörler ile güncellenmiştir [15]. Bu çalışmada, AFAD tarafından işletilen Türkiye Ulusal Kuvvetli Yer Hareketi Gözlem Ağı kayıtlarından elde edilen 24 Ocak 2020 Mw 6,8 Elazı̆̆/Sivrice depremi kayıtlarının yer hareketi parametreleri (en yüksek yer ivmesi, spektral ivme) yakın zamanda güncellenen 2014 NGA ilişkileri ile uyumluluğu değerlendirilmiştir. [16] (ASK14), [17] (BSSA14) ve [18] (CY14) YHTD'leri, deprem merkez üssünden 150 km'ye kadar uzaklıkta olan istasyonlardan elde edilen yer hareketi verilerinin değerlendirilmesinde kullanılmıştır.

Şekil 6, Şekil 7 ve Şekil 8'de Mw 6,8 Sivrice depremi için istasyon bilgileri ve NGA [15]. -2014 YHTD'leri [3] siras1 ile [16]. (ASK14), [17] (BSSA14) ve [18] (CY14) kullanılarak elde edilen PGA- Rrup (fay kırığına en yakın mesafe) ilişkisi grafikleri $\mathrm{V}_{\mathrm{s}, 30}=360 \mathrm{~m} \mathrm{~s}-1$ ve $\mathrm{V}_{\mathrm{s}, 30}=760 \mathrm{~m} \mathrm{~s}^{-1}$ değerleri için çizilmiştir. YHTD'den elde edilen PGA- Rrup ilişkisi ( \pm ) standart sapma değerleriyle birlikte hesaplanmıştır. Elde edilen PGA değer aralığı yatay bileşen olarak hesaplanmıştır. Hesaplanan PGA değerleri, istasyon kayıtlarından elde edilen iki yatay bileşenin en büyük değeri (PGA), istasyonun fay kırığına olan en yakın mesafesi ile birlikte kıyaslanmıştır.

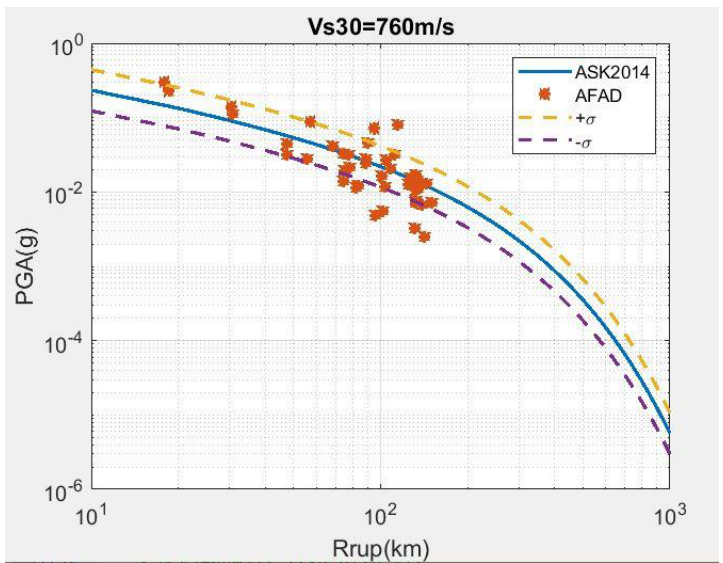

(a)

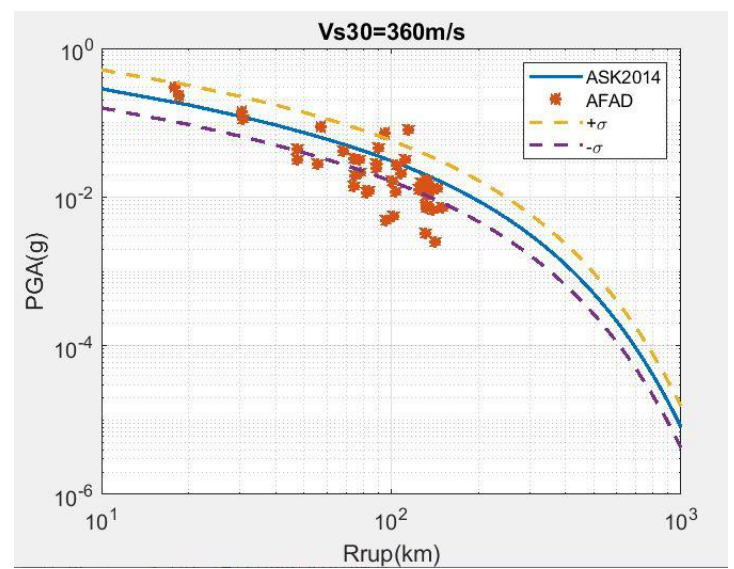

(b)

Şekil 6. $2020 \quad \mathrm{Mw} \quad 6.8$ Sivrice depremi Vs, 30=760 m s-1 (a) ile Vs, 30=360 m s1 (b) PGA-Rrup analizi (ASK14) [16]

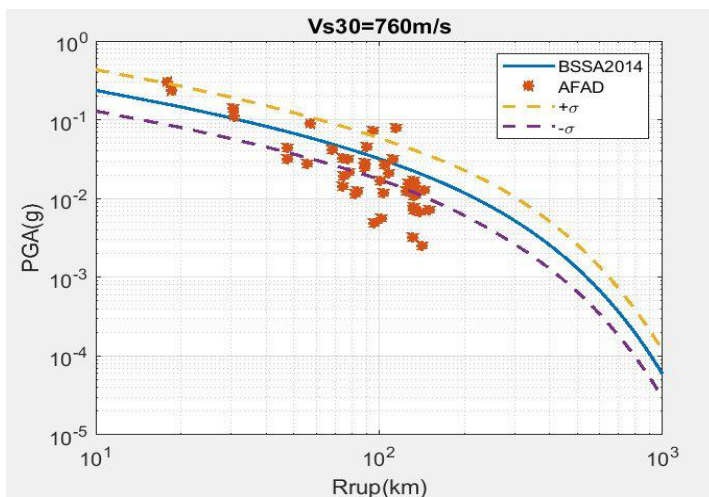

(a)

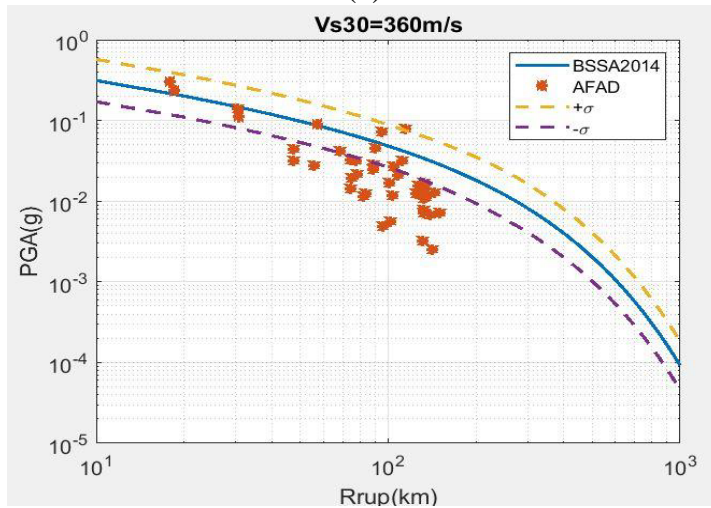

(b)

Şekil 7. 2020 Mw 6.8 Sivrice depremi $\mathrm{V}_{\mathrm{s}, 30}=760 \mathrm{~m}$ $\mathrm{s}-1$ (a) ile $\mathrm{V}_{\mathrm{s}, 30}=360 \mathrm{~m} \mathrm{~s}-1$ (b) PGA-Rrup analizi (BSSA14) [17] 


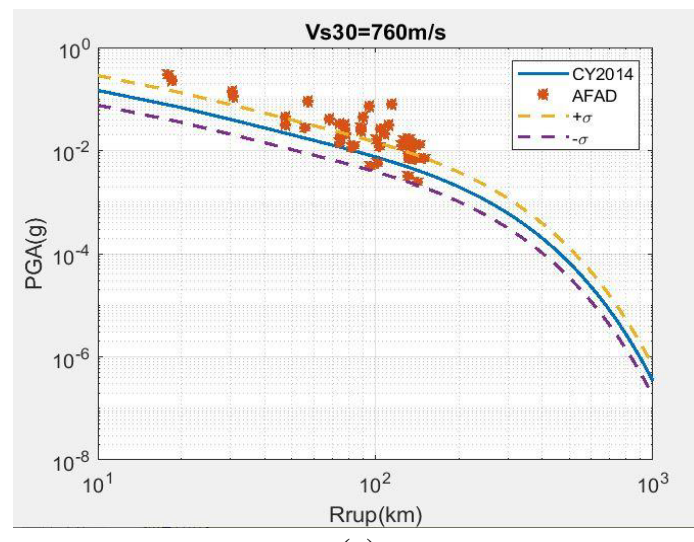

(a)

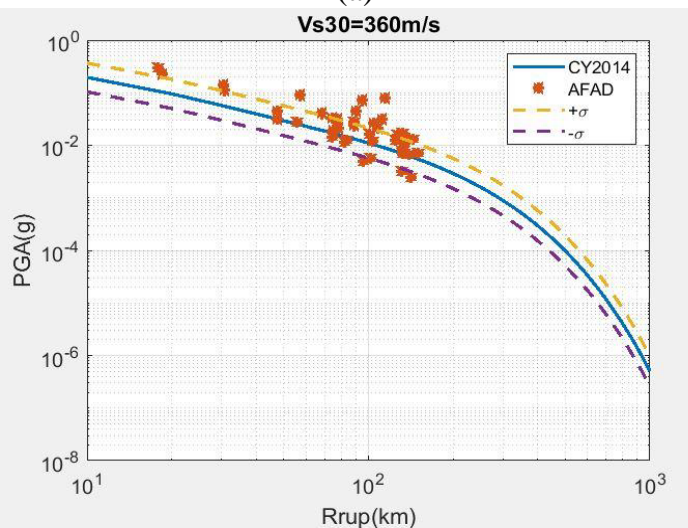

(b)

Şekil 8. $2020 \mathrm{Mw} 6.8$ Sivrice depremi $\mathrm{V}_{\mathrm{s}, 30}=760 \mathrm{~m}$ $\mathrm{s}^{-1}$ (a) ile $\mathrm{V}_{\mathrm{s}, 30}=360 \mathrm{~m} \mathrm{~s}^{-1}$ (b) PGA-Rrup analizi (CY14) [18]

Mw6.8 Sivrice depremine ait $150 \mathrm{~km}$ içindeki AFAD istasyonlarından alınan kayıtların maksimum yer ivmesi değerleri PGA-Rrup analizi sonucunda $\mathrm{V}_{\mathrm{s}, 30}=760 \mathrm{~m} \quad \mathrm{~s}-1$ olduğu durumda ASK14 [16] sonuçlariyla daha uyumlu olduğu görülmüştür.

En yakın istasyonlar olan Sivrice (2308), Pütürge (4404) ve Merkez (2301) istasyon kayitlarına ait spektral ivmeler hesaplanmış olup depreme ait bilgiler ASK14 [16], BSSA14 [17] ve [18] yer hareketi tahmin denklemlerinde kullanılarak elde edilen spektrum eğrileri, istasyon kayıtlarından elde edilen spektrum eğrileriyle karşılaştırılmıştır. Bu karşılaştırmalar Şekil 9'da sırasıyla Sivrice (2308), Pütürge (4404) ve Merkez (2301) istasyonları için gösterilmiştir. Şekil 9'da görüldüğü gibi, Sivrice (2308) ve Pütürge (4404) istasyonlarına ait YHDT (ASK14, BSSA14, CY14)'den elde edilen spektrum eğrilerinin bu istasyonların ivme verisinin davranış spektrumu ile uyumlu olmadığı görülmektedir. 2301 ElazığMerkez İstasyonu için YHDT'den elde edilen spektrum eğrisinin istasyon kaydından elde edilen spektrum eğrisiyle özellikle kısa periyot alanında ( $>1,0$ saniye) daha çok uyumlu olduğu görülmüştür. Ayrıca, Elazı ğ-Merkez istasyonundan elde edilen kayda ait spektrum eğrisinin 2014 YHTD'leri ile daha uyumlu olduğu görülmüştür.

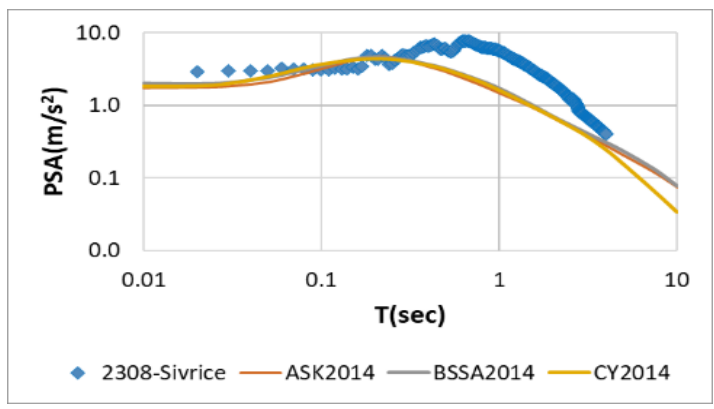

(a)

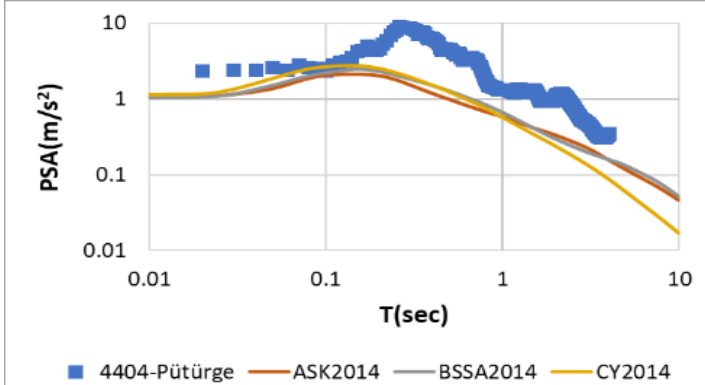

(b)

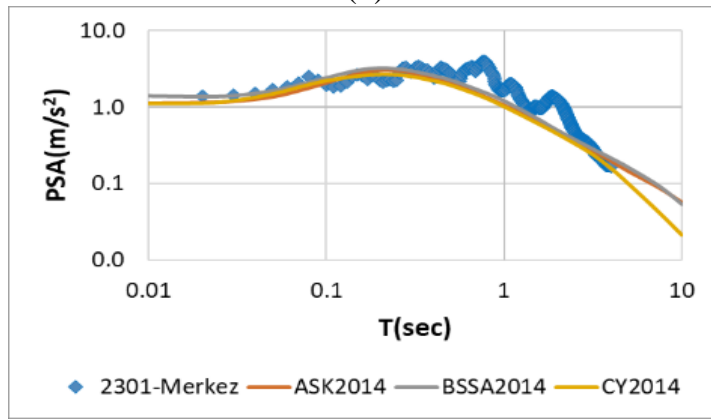

(c)

Şekil 9. ASK14 [16], BSSA14 [17], CY [18] ile Sivrice depremi AFAD istasyonu PSa analizi 
AFAD istasyonlarından alınan yer hareketi kayıtları davranış spektrumlarının, Sivrice (2308) istasyonu konumu için ZC zemin durumuna bağlı olarak DD-2 ve DD-3 seviyeleri [19] tasarım deprem spektrumları ve TSC2007 yönetmeliğinde ZC zemin koşullarına ait tasarım spektrumlarıyla karşılaştırmaları Şekil 10'da gösterilmiştir. İstasyonlardan alınan deprem kayıtlarından elde edilen davranış spektrumu eğrilerinin, her iki deprem seviyesi için de tüm periyotlarda [19] tasarım spektrumu eğrilerinin altında kaldığ 1 görülmüştür. Deprem merkezine en yakın istasyonlar olan 2308 ve 4404 istasyonlarından alınan ivme verisine ait spektrum eğrisinin DD-3 seviyesindeki deprem sepktrumuyla özellikle plato bölgesinde uyumlu olmadığı, spektrumun altında kaldığı gözlenmiştir. Fakat deprem merkezinden $50 \mathrm{~km}$ uzaklikta bulunan istasyonların spektrumlarının deprem tasarım seviyesi olan DD2 seviyesindeki deprem durumuna ait spektrum eğrisinin altında kaldığ 1 gözlenmiştir. TSC2007 $\mathrm{A}_{0}=0,3 \mathrm{~g}$ ve $\mathrm{A} 0=0,2 \mathrm{~g} \mathrm{ZC}$ zemin sinifina ait spektrumlarının 2308 ve 4404 istasyonlarına ait spektrumlar tarafından aşıldığı gözlenmiştir. Sonuç olarak, [18] DD2-ZC tasarım spektrumunun, deprem merkezine maksimum $50 \mathrm{~km}$ uzaklıkta bulunan AFAD istasyon kayıtlarına ait spektrumları kapsadığı gözlenmiştir.

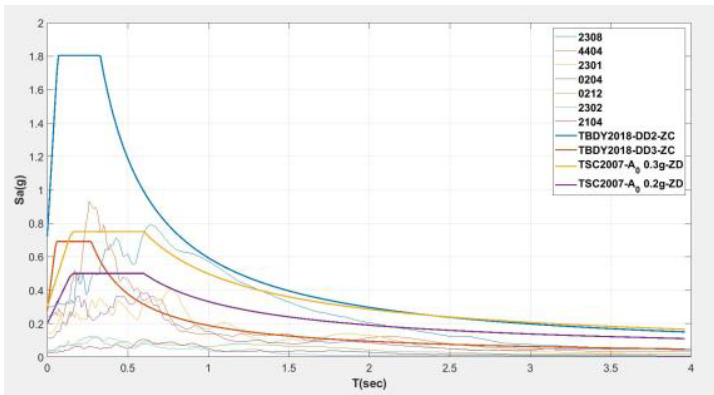

Şekil 10. DD2- ve DD-3 deprem seviyelerine ait tasarım spektrumları (2007-2018) ve kayıtlardan elde edilen davranış spektrumlarının karşılaştırılması

\subsection{Deprem Yer Hareketi Parametreleri Dağılımı Analizi}

Çalışma kapsamında; depremin büyüklüğü, merkez üssü konumu, kaynaktan uzaklık ve kaynak mekanizma çözümüne ait veriler [1]'den alınmıştır. Zemin koşulları ve CY14 (Chiou ve Youngs, 2014)'deki yer hareketi tahmin denklemi kullanılarak yer hareketi parametreleri sirasi ile Şiddet, En büyük ivme, Spektral ivme 0,2 s, Spektral ivme 1,0 s (MMI, PGA, Sa 0,2 s, Sa 1,0 s) dağılım haritaları elde edilmiştir. Çizelge 3'de analizde kullanılan fay mekanizma parametreleri (strike, dip, rake) değerleri [1]'den alınmıştır.

Çizelge 3. 24 Ocak $2020 \mathrm{Mw} \mathrm{6,8} \mathrm{Sivrice} \mathrm{(Elazığ)}$ depremi moment tensör çözümü [1]
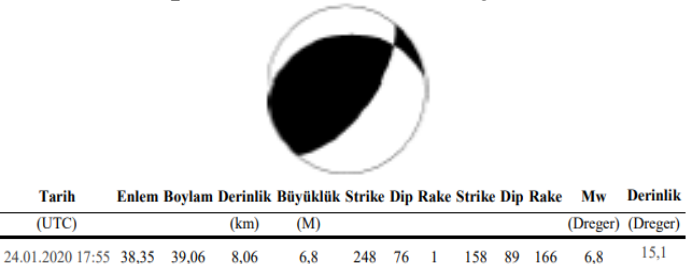

Kuvvetli yer hareketi kayıtlarının incelenmesinde, YHDT'den ASK14 [16], BSSA14 [17], CY14 [18] bağıntıları çalışılmış, yapılan değerlendirmeler sonucunda ASK14 [16]'ün Mw 6.8 Sivrice (Elazığ) depremi yer hareketi kayıtları ile uyumlu olduğu görülmüştür. Deprem yer hareketi parametreleri dağılım analizinde de ASK14 [16] kullanılmıştır. Analizde SHARE [20] kaynaklarından Doğu Anadolu Fay zonunun üzerinde bulunan Pütürge Segmenti kullanıldı. Bu fayın sol yönlü doğrultu atımlı fay mekanizması ile uyumlu olduğu görülmüştür [1]. Analizde ayrıca mühendislik ana kayası $\left(\mathrm{V}_{\mathrm{s}, 30}=760 \mathrm{~m} / \mathrm{s}\right)$ referans zemin koşulları kullanılmıştır.

ASK14 modeli [22] (AS08) modelinin NGAWest-2 verilerine dayanarak güncellenmiş hali şeklindedir. Modelin input parametreleri AS08 modelinden kullanılan değerlere benzer şekildedir. Dahil edilen değişiklikler;

- Non-linear zemin etkileri için yükleme seviyesi PGA'dan ziyade ilgili periyodun spektral ivmesine dayanır,

- Tavan taşı (hanging wall, HW) etkileri için uzaklık skalası kaynak-zemin azimuthta bağl1lık içerir, 
- Geniş uzaklık azalımında bölge etkileri ve Kaliforniya, Çin, Japonya, Tayvan arasından zemin artım skalası birleştirilmiştir,

- HW etkileri için skalalar nümerik simülasyonların kısıtlamalarına dayanarak geliştirilmiştir,

- Standart sapma kısa periyotta daha büyük standart sapmalar ile sonuçlanan daha küçük magnitüdler ile magnitüde bağlıdır fakat uzun periyotlarda daha küçük standart sapmalar ve eski modelden farklı küçüklü büyüklüklü olaylar $(\mathrm{Mw}=3)$ güncel versiyonda dahil edilmiştir.

ASK14 denklemi Eşitlik 1'de verilmiştir.

$\operatorname{lnSa}(\mathrm{g})=\mathrm{f} 1\left(\mathrm{M}, \mathrm{R}_{\mathrm{rup}}\right)+\mathrm{F}_{\mathrm{RV}} \mathrm{f}_{7}(\mathrm{M})+\mathrm{F}_{\mathrm{N}} \mathrm{f}_{8}(\mathrm{M})+\mathrm{F}_{\mathrm{AS}} \mathrm{f}_{11}$ $\left(\mathrm{CR}_{\mathrm{jb}}\right)+\mathrm{f}_{5}\left(\mathrm{Sa}_{1180}, \mathrm{~V}_{\mathrm{s}, 30}\right)+\mathrm{F}_{\mathrm{HW}} \mathrm{f}_{4}\left(\mathrm{R}_{\mathrm{jb}}, \mathrm{R}_{\mathrm{rup}}, \mathrm{R}_{\mathrm{X}}, \mathrm{W}\right.$, dip,

$\left.\mathrm{Z}_{\mathrm{TOR}}, \mathrm{M}\right)+\mathrm{f}_{6}\left(\mathrm{Z}_{\mathrm{TOR}}\right)+\mathrm{f}_{10}\left(\mathrm{Z}_{1.0}, \mathrm{~V}_{\mathrm{s} 30}\right) \operatorname{Reg}\left(\mathrm{V}_{\mathrm{s}, 30}, \mathrm{R}_{\mathrm{rup}}\right)$

Burada f1 doğrultu atımlı depremlere bağlı uzaklık ve büyüklüğün en basit formudur, f7 ve f8 fay modelinin stili için fonksiyonlardır, f11 artçı şok skala fonksiyonudur, f5 kaya zeminde medyan spektral ivme kullanılarak oluşturulan zemin tepki modelidir, f4 tavan taşı (hanging wall) modelidir, f6 yarılmanın üst derinlik modeli, f10 zemin derinlik modeldir. $\mathrm{Bu}$ modelde $\mathrm{V}_{\mathrm{s}, 30}$ 'un farklılığ ayrıca eklenmiştir.

[23],[24] çalışmalarında PGA ve PGV yer hareketi parametreleri ile Değiştirilmiş Mercalli Şiddeti $\left(\mathrm{MMI}^{-\mathrm{I}} \mathrm{mm}\right)$ arasındaki dönüşüm bağıntıları, şiddet dağılımı tahmininde kullanılmıştır. Bu bağıntılar büyüklükleri 5,8 ile 7,3 arasında değişen önemli 8 farklı Kaliforniya depremleri verileri kullanılarak geliştirilmiştir $[23,24]$. Bu bağıntılar aşağıdaki gibidir,

Şiddet tahmini için PGA ile ilişkilendirilen, $\mathrm{V}<\mathrm{I}_{\mathrm{mm}}<$ VIII aralığı için,

Şiddet tahmini için PGV ile ilişkilendirilen, V $<$ I_mm $<$ IX aralığg için (Eşitlik 2),

$I_{m m}=3,66 \log ($ PGA $)-1,66 \quad(\sigma=1,08)$
Şiddet tahmini için PGV ile ilişkilendirilen, $\mathrm{V}<I_{m m}<\mathrm{IX}$ aralığ 1 için (Eşitlik 3),

$\mathrm{I}_{\mathrm{mm}}=3,47 \log (\mathrm{PGV})+2,35 \quad(\sigma=1,08)$

Yer hareketi parametreleri (MMI, PGA, $\mathrm{S}_{\mathrm{a}} 0,2$, $\left.\mathrm{S}_{\mathrm{a}} 1,0\right)$ dağılım analizi sonuç haritaları sırası ile Şekil 11 ile Şekil 14 arasında verilmiştir. Şekil 11'de şiddet dağılımı (MMI), Şekil 12'de PGA, Şekil 13'de Sa (T=0,2 s), Şekil 14'de $\mathrm{Sa} \quad(\mathrm{T}=1,0 \mathrm{~s})$ dağılımları gösterilmiştir. Sonuç haritalarına göre yer hareketi parametrelerinin en yüksek değerleri merkez üssüne en yakın olan Sivrice ve çevresinde görülmüş olup, merkez üssünden uzaklaştıkça azalmıştır.

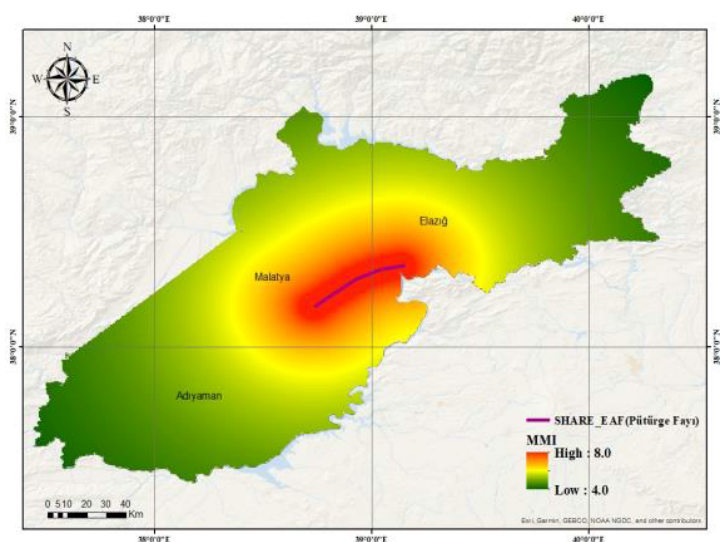

Şekil 11. Mw 6,8 Sivrice (Elazı̆̆) depreminin ASK14 [16]'e göre hazırlanan MMI şiddet dağılım haritası

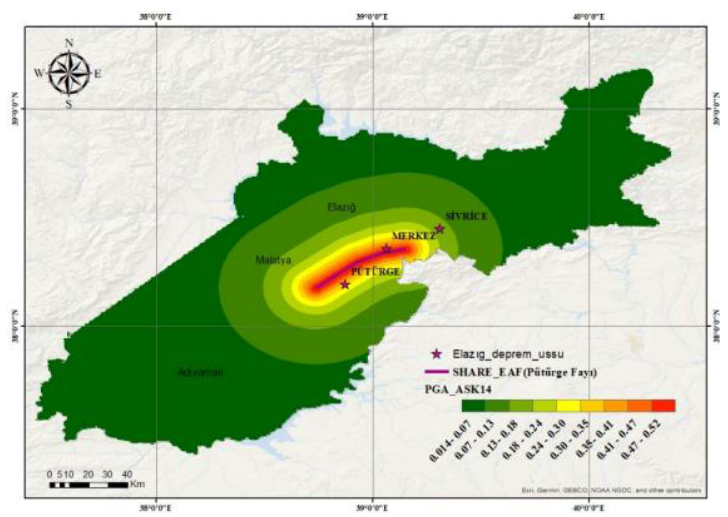

Şekil 12. Mw 6,8 Sivrice (Elazı̆̆) depreminin ASK14 [16]'e göre hazırlanan en büyük ivme dağılım (PGA) haritası 


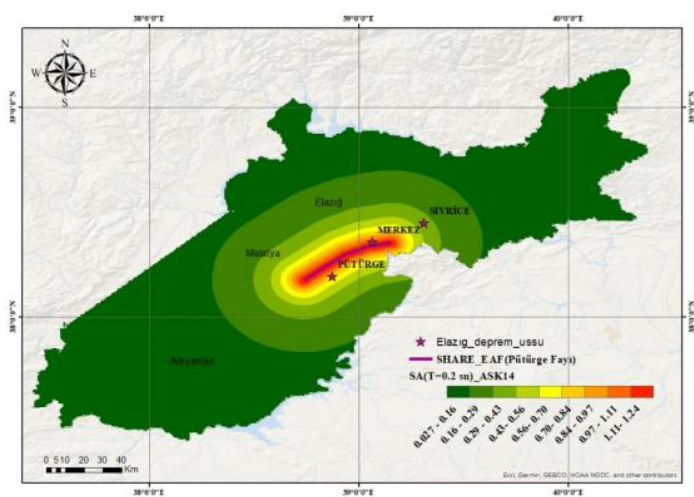

Şekil 13. Mw 6,8 Sivrice (Elazığ) depreminin ASK14 [16]'e göre hazırlanan $\mathrm{Sa}(\mathrm{T}=0,2$ s) Spektral ivme dağılım haritas1

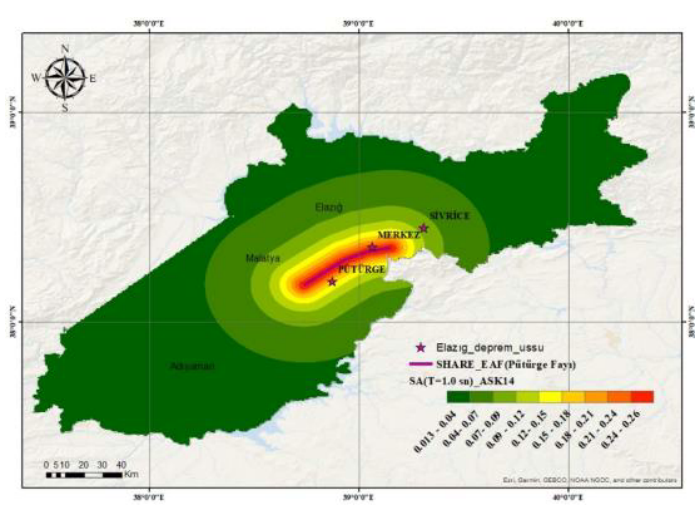

Sekil 14. Mw 6,8 Sivrice (Elazığ) depreminin ASK14 [16]'e göre hazırlanan $\mathrm{Sa}(\mathrm{T}=1,0$ s) Spektral ivme dağılım haritas1

\section{3. Öncü ve Artçı Depremler ile Deprem Enerjisinin Değerlendirilmesi}

Bölgede 20 0cak-27 Nisan 2020 tarihlerinde 4322 deprem meydana gelmiştir $[14]^{2}$. Meydana gelen bu depremlerin büyüklükleri M 0,8 ile M 6,8 arasında değişmektedir. $\mathrm{M} \geq 4,0$ olan deprem sayısı ise 30 adettir. Depremlerin derinlikleri de incelendiğinde çoğunluğunun derinliği 7 ile 47,94 $\mathrm{km}$ arasındadır ve derinliklerin ortalaması da 7,0 $\mathrm{km}$ civarındadır. Bunları içindeki Mw 6,8 büyüklüğündeki Sivrice (Elazığ) depreminin de derinliği $8,06 \mathrm{~km}$ ile ortalama değer civarındadır. Şekil 15a'da söz konusu tarihler arasında meydana gelen deprem sayıs1 ve büyüklük (Magnitüd) bilgisi ve Şekil $15 b$ 'de ise deprem sayısı-derinlik bilgisi verilmiştir. AFAD'dan alınan bu depremler incelendiğinde depremlerin magnitüd değerlerinin $M w$ ve ML cinsinden olduğu görülmüştür. Burada Mw magnitüdleri aynı alınırken ML magnitüdleri ise (Eşitlik 4);

$$
\mathrm{Mw}=0,8095( \pm 0,031) \mathrm{M}_{\mathrm{L}}+1,3003\left(3,3 \leq \mathrm{M}_{\mathrm{L}} \leq 6,6\right)
$$

Eşitlik 4 denklemi kullanılarak dönüşüm yapılmıştır [25].

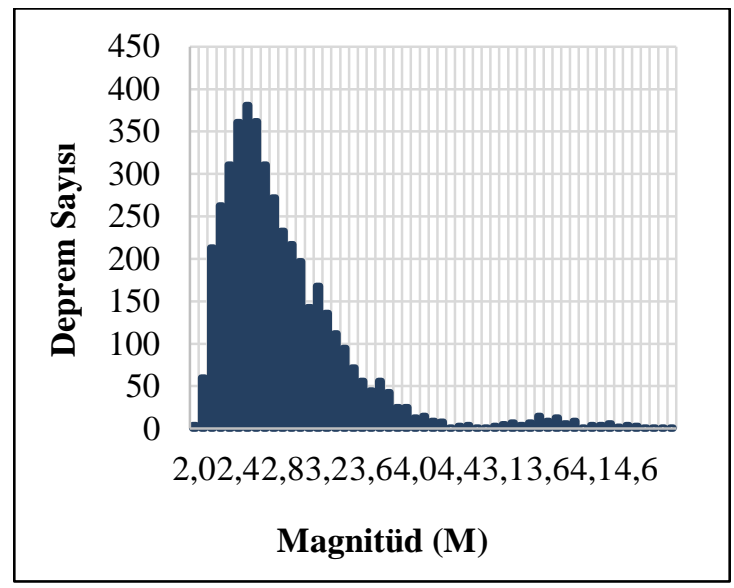

(a)

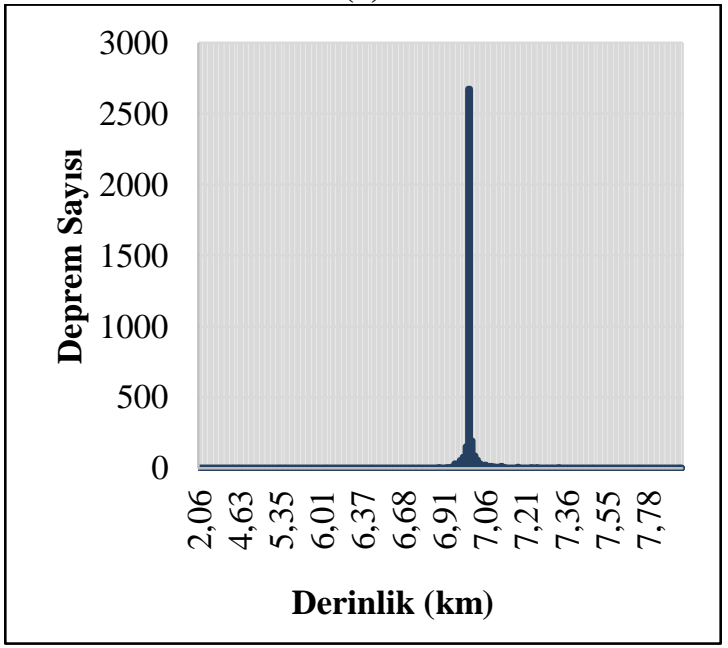

(b)

Şekil 15. Elazığ (Sivrice) bölgesi Deprem sayıs1magnitüd (a) ve deprem sayısı-derinlik (b), grafikleri 
Şekil 16'de incelenen 4 aylık periyot içerisindeki deprem sayısı dağılımı verilmiştir. İlk iki günde ortalama aynı deprem sayısı meydana gelmiş, $\mathrm{Mw}$ 6,8'lik Sivrice depremini de içinde bulunduran sonraki on iki günde ise ciddi bir artış olmuştur ve sonrasında deprem sayısı giderek azalmıştır. 24.01.2020 günü ana şokun olduğu tarihte 159 adet irili ufaklı depremler meydana gelmiştir [14].

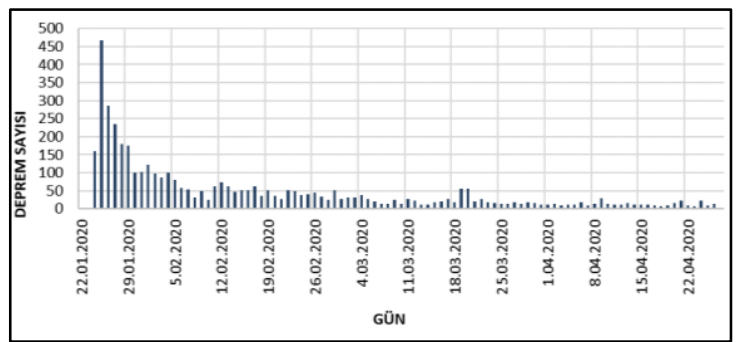

Şekil 16. Deprem sayısı-gün grafiği

Elazı̆̆ (Sivrice) depreminin dört aylık depremselliğine bakıldığında, Şekil 17a,b'de görüldüğü gibi ana şoktan sonraki zaman içeresinde kümülatif olarak deprem sayısının ve deprem enerjisinin büyük kısmının ilk zamanlarda boşaldığı görülmektedir. Burada deprem enerjisinin tespiti için $\log \mathrm{E}=11,8+1,5 \mathrm{Ms}$ ampirik bağıntısı kullanılmış, [E, enerji birimi erg ( 1 erg $=10-7$ joule $)$ ve Ms ise yüzey magnitüdü temsil etmektedir [27]. Alınan verilerdeki tüm magnitüd değerleri yüzey magnitüdü olmadığından önce yüzey magnitüdüne çevrilmiş sonrasında enerji hesabı yapılmıştır.

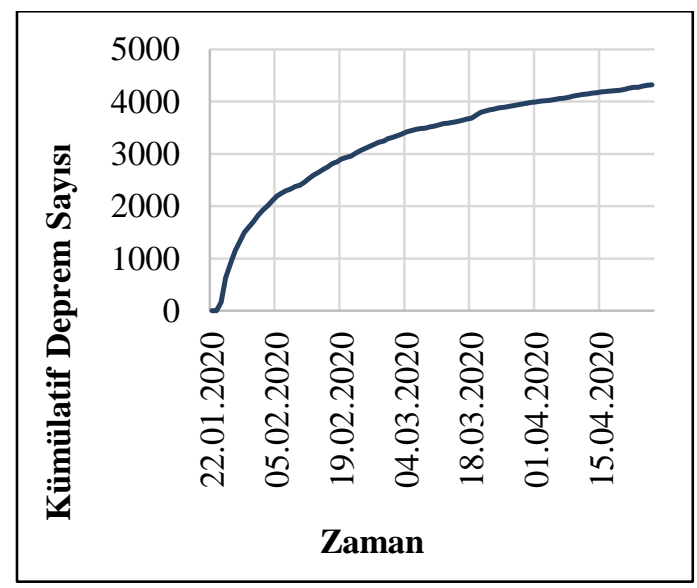

(a)

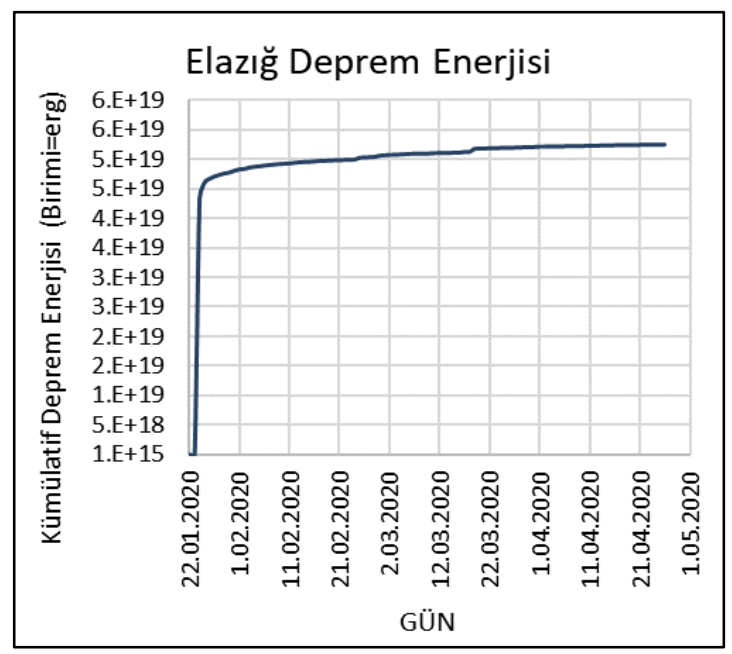

(b)

Şekil 17. Kümülatif deprem sayısı-gün (a) ve kümülatif deprem enerjisi-gün (b), grafikleri

Çalışma kapsamında Mw 6,8 Elazı̆̆ (Sivrice) depreminin ülkemizde yakın geçmişte meydana gelen büyük ve ciddi hasar yapıcı depremler olan 2011 Van Mw 7,2 [28] ve 1999 Kocaeli Mw 7,6 [14] depremlerinde açı̆̆a çıkan enerjiler ile karşılaştırılması yapılmıştır (Şekil 18).

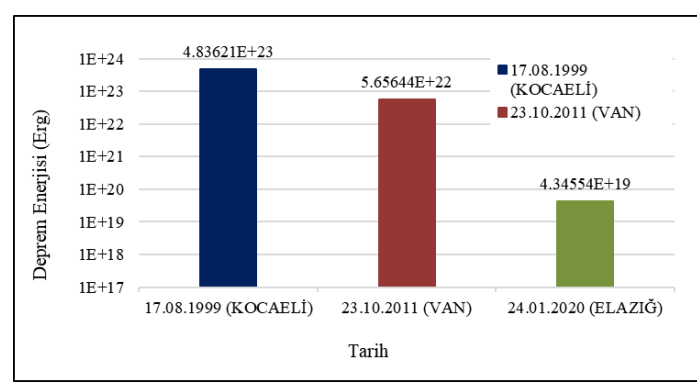

Şekil 18. Kocaeli, Van ve Elazı̆g (Sivrice) depremlerinin ana şokta ortaya çıkan enerjileri

2011 Van Depremi Mw 7,2 için 3 aylık deprem verisi incelenmiştir. 23 Ekim-30 Aralık 2011 tarihleri arasında 180 adet deprem meydana geldiği tespit edilmiştir. $\mathrm{Bu}$ depremlerin genel magnitüd aralığı M 4,0-M 5,0 arasındadır. 23 Ekim 2011 günü meydana gelen $\mathrm{Mw} 7,2$ büyüklüğündeki deprem bölgede ciddi yapısal hasara sebep olmuştur. Oluşan bu depremle (5,66x1022) Erg 
seviyesinde ciddi bir enerji açığa çıkmış sonrasındaki artçı depremlerde ciddi bir değişiklik gözlenmemiştir. Moment enerjisinin büyük kısmı ana şokta boşalmıştır.

1999 Kocaeli Depremi Mw 7,6 için 6 aylık bir veri ele alınmıştır. 01 Haziran-30 Kasım 1999 tarihleri arasındaki veriler incelenmiştir. $\mathrm{Bu}$ tarihler arasında AFAD verilerine göre 324 deprem ölçülmüştür. $\mathrm{Bu}$ depremlerin magnitüd aralığ M 2,9 ile M 7,6 arasında değişmektedir ve ortalama olarak oluşan depremlerin magnitüd değeri M 4,7'dir. 17 Ağustos 1999'da meydana gelen M 7,6 büyüklüğündeki depremin açı̆̆a çıkardığı enerji (4,83x1023) Erg seviyesinde olup, enerjisinin büyük kısmının ana şok ile boşaldığı görülmektedir.

1999 Kocaeli Mw 7,6 depremi, 2011 Van Mw 7,2 depremi ve 2020 Elazığ (Sivrice) Mw 6,8 depreminin meydana getirdiği kümülatif enerji karşılaştırması yapıldığında 7,6 büyüklüğündeki Kocaeli depreminin enerjisinin $10^{23} \mathrm{Erg}, \quad 7,2$ büyüklüğündeki Van depreminin enerjisinin $10^{22} \mathrm{Erg}, \quad 6,8$ büyüklüğündeki Elazığ-Sivrice depreminin enerjisinin de $10^{19}$ Erg mertebelerinde olduğu hesaplanmıştır.

\section{SONUÇLAR}

Bu çalışma kapsamında 24 Ocak 2020 günü Elazığ-Sivrice merkezli meydana gelen Mw 6,8 büyüklüğündeki depremin en çok etkilediği bölgelere ait tarihsel ve aletsel dönem depremselliği ve bu deprem sırasında kaydedilen kuvvetli yer hareketi kayıtları incelenmiştir. Ms=6,8 büyüklüğünde 4 Aralık 1905 tarihinde gelişen depremden sonra bölgede gelişen en büyük deprem 24 Ocak 2020 Mw 6,8 Elazığ depremi olması sebebiyle önem arz etmektedir.

Deprem Elazı̆̆ başta olmak üzere Doğu ve Güneydoğu Anadolu bölgelerindeki bir çok ilde hissedilmiştir. Çalışma kapsamında bölge sismotektoniği gözden geçirilmiş, bölgede tarihsel ve aletsel dönemde meydana gelen depremler değerlendirilmiştir. Deprem sırasında kaydedilen Maksimum Yer ivmesi-PGA değerleri ASK14 [16], BSSA14 [17], ve CY14 [18] NGA2014
YHTD kullanılarak değerlendirilmiştir. Ayrıca CY14 YHTD kullanılarak yer hareketi parametreleri (MMI, PGA, Sa0,2, Sa1,0) dağılım haritaları oluşturulmuş ve kaydedilmiş yer hareket parametreleri ile karşılaştırılmıştır. Çalışmanın son kısmında ana şok öncesi ve sonrası öncü ve artç1 depremler ve açığa çıkan enerji değerlendirilmiş ve ülkemizde yakın geçmiş zamanda meydana gelen yıkıcı depremler 1999 Kocaeli (Mw 7,6) ve 2011 Van (Mw 7,2) depremleri ile karşılaştırılmıştır.

\section{TEŞEKKÜR}

Çalışmaya verdikleri katkılarından dolayı araştırmacılar Dr. Senem TEKİN, Yüksek İnşaat Mühendisi Seyhan OKUYAN AKCAN ve Yüksek İnşaat Mühendisi Methiye GÜNDOĞDU GÖK'e teşekkür ederim.

\section{KAYNAKLAR}

1. T.C. İçişleri Bakanlığı Afet ve Acil Durum Yönetimi Başkanlığ 1 2020. 20 Ocak 2020 Sivrice Elazı ̆ Depremi Mw 6,8 Depremine İlişkin ön Değerlendirme Raporu.

2. Maden Tetkik ve Arama Genel Müdürlüğü, 2020. 20 Ocak 2020 Sivrice Elazığ Depremi Bilgi Notu, 1-5.

3. Douglas, J., 2019. Ground Motion Prediction Equations, United Kingdom, Glasgow: University of Strathclyde, 1964.

4. Emre, Ö., Duman, T.Y., Özalp, S., Elmac1, H., Olgun, Ş., Şaroğlu, F., 2013. Açıklamalı Türkiye Diri Fay Haritası. Ölçek 1:1.250.000, Maden Tetkik ve Arama Genel Müdürlüğü, Özel Yayın Serisi-30, Ankara-Türkiye, 89.

5. Hempton, M.R., 1985. Structure and Deformation History of the Bitlis Sture Near Lake Hazar, South Eastern Turkey. Geol.Soc.Am.Bull. 96, 233-243.

6. Arpat, E., Şaroğlu, F., 1972. Doğu Anadolu Fayı ile İlgili Gözlemler ve Düşünceler. Maden Tetkik ve Arama Enstitüsü Dergisi, 78, 44-50.

7. Dewey, J.F., Hempton, M.R., Kidd, W.S.F., Saroglu, F., Sengör, A.M.C., 1986. Shortening of Continental Lithosphere: the Neotectonics of Eastern Anatolia: A Young Collision Zone. In: Coward, M.P., Ries, A.C. (Eds.), Collision 
Tectonics. Geol. Soc. Lond. Spec. Publ. 19 3-36.

8. Allen, M., Jackson, J., Walker, R., 2004. Late Cenozoic Reorganization of the ArabiaEurasia Collision and the Comparison of Shortterm and Long-term Deformation Rates. Tectonics 23 (1), TC2008.

9. Westaway, R., 1994. Present-day Kinematics of the Middle East and Eastern Mediterranean. J. Geophys. Res. 99, 12071-12090.

10. Aksoy, E., İnceöz, M., Koçyiğit, A., 2007. Lake Hazar Basin: A Negative Flower Structure on the East Anatolian Fault System (EAFS), SE Turkey, Turkish Journal of Earth Sciences, 16, 319-338.

11. Bulut, F., Bohnhoff, M., Eken, T., Janssen, C., Kl, T., Dresen, G.,2012. The East Anatolian Fault Zone: Seismotectonic Setting and Spatiotemporal Characteristics of Seismicity Based on Precise Earthquake Locations Journal of Geophysical Research B: Solid Earth, 117 (7), Art. no. B07304.

12. Kadirioğlu, F.T., Kartal, R.F., Kılıç, T., Kalafat, D., Duman, T.Y., Eroğlu Azak, T., Özalp, S., Emre, Ö., 2016. Türkiye ve Yakın Çevresi için Geliştirilmiş Aletsel Dönem (1900 -2012) Deprem Katalogu ( $M \geq 4,0)$. Türkiye Sismotektonik Haritası (Ed. T.Y. Duman), MTA Özel Yayınlar Serisi-35, 249.

13. Başarır Baştürk, N., Özel, N.M., Altınok, Y., Duman, T.Y., 2016. Türkiye ve Yakın Çevresi için Geliştirilmiş Tarihsel Dönem (MÖ 2000MS 1900-) Deprem Katalogu. Türkiye Sismotektonik Haritası Açıklama Kitabı, MTA Özel Yayınlar Serisi-35, 249.

14. Anonim1, 2020. https://deprem.afad.gov.tr/, T.C. İçişleri Bakanlığı Afet ve Acil Durum Yönetimi Başkanlığı, Deprem Dairesi Başkanlığı, (Erişim Tarihi:30.10.2020).

15. Bozorgnia, Y., Abrahamson, N.A., Atik, L.A., Ancheta, T.D., Atkinson, G.M., Baker, J.W., Baltay, A., Boore, D.M., Campbell, K.W., Chiou, B.S.J., Darragh, R., Day, S., Donahue, J., Graves, R.W., Gregor, N., Hanks, T., Idriss, I.M., Kamai, R., Kishida, T., Kottke, A., Mahin, S.A., Rezaeian, S., Rowshandel, B., Seyhan, E., Shahi, S., Shantz, T., Silva, W., Spudich, P., Stewart, J.P., Watson-Lamprey Wooddell, K., Youngs, R., 2014. NGA-West2
Research Project. Earthquake Spectra, 30, 973-987.

16. Abrahamson, N.A., Silva, W.J., Kamai, R., 2014. Summary of the ASK14 Ground Motion Relation for Active Crustal Regions. Earthquake Spectra, 30(3), 1025-1055.

17. Boore, D.M., Stewart, J.P., Seyhan, E., Atkinson, G.M., 2014. NGA-West2 Equations for Predicting PGA, PGV, and 5\% Damped PSA for Shallow Crustal Earthquakes. Earthquake Spectra, 30(3), 1057-1085.

18. Chiou, B.S.J., Youngs, R.R., 2008. An NGA Model for the Average Horizontal Component of Peak Ground Motion and Response Spectra. Earthquake Spectra, 24(1), 173-215.

19. TBDY-2018. Deprem Etkisi Altında Binaların Tasarımı için Esaslar, http://www. resmigazete.gov.tr/eskiler/2018/03/20180318M 1-2-1.pdf, 416.

20. Woessner, J., Laurentiu, D., Giardini, D., Crowley, H., Cotton, F., Grünthal, G., Valensise, G., Arvidsson, R., Basili, R., Demircioglu, M.B., Hiemer, S., Meletti, C., Musson, R.W., Rovida, A.N., Sesetyan, K., Stucchi, M., 2015. The 2013 European Seismic Hazard Model: key components and results. Bull Earthquake Eng 13, 3553-3596.

21. Pagani, M., Monelli, D., Weatherill, G., Danciu, L., Crowley, H., Silva, V., Henshaw, P., Butler, L., Nastasi, M., Panzeri, L., Simionato, M., Vigano, D., 2014. OpenQuake Engine an Open Hazard (and Risk) Software for the Global Earthquake Model, Seismological Research Letters, 85(3), 692-702.

22. Silva, W.J., 2005. Site Response Simulations for the NGA Project. Report Prepared for the Pacific.

23. Earthquake Engineering Research Center.

24. Wald, D.J.V., Quitoriano, T.H., Heaton, H., Kanamori, C.W., Scrivner, C.B., Worden, T.S., 1999a. Rapid Generation of Instrumental Ground Motion and Intensity Maps for Earthquakes in Southern California, Earthquake Spectra, 15, 537-556.

25. Wald, D.J.V., Quitoriano, T.H., Heaton, H., Kanamori, C.W., 1999b. Relationship Between Peak Ground Acceleration, Peak Ground Velocity, and Modified Mercalli Intensity for 
Earthquakes in California, Earthquake Spectra, 15(3), 557-564.

26. Kadirioğlu, F.T., Kartal, R.F., 2016. The New Empirical Magnitude Conversion Relations Using an Improved Earthquake Catalogue for Turkey and its Near Vicinity (1900-2012). Turkish Journal of Earth Sciences 25(4), 300-310.

27. Gutenberg, B., Richter, C.F., 1956. Earthquake Magnitude, Intensity, Energy, and Acceleration: (Second paper). Bulletin of the Seismological Society of America, 46(2), 105-145.

28. Kramer, S.L., 1996. Geotechnical Earthquake Engineering, Environmental \& Engineering Geoscience, 653.

29. KRDAE, 2011. Boğaziçi Üniversitesi Kandilli Rasathanesi ve Deprem Araştırma Ensitüsü, 2011. 23 Ekim 2011 Van Depremi $(\mathrm{Mw}=7,2)$ Değerlendirme Raporu, 1-3, 2011. 